Article

\title{
4PL Digital Business Models in Sea Freight Logistics: The Case of FreightHub
}

\author{
Tim Gruchmann ${ }^{1, *}$, Nadine Pratt ${ }^{2} \mathbb{D}$, Jan Eiten ${ }^{3}$ and Ani Melkonyan ${ }^{3}$ \\ 1 Institute of Management and Tourism (IMT), Westcoast University of Applied Sciences, 25746 Heide, Germany \\ 2 Competence Centre for Sustainable Development, FOM University of Applied Sciences, 45127 Essen, \\ Germany; nadine.pratt@fom-net.de \\ 3 Centre for Logistics and Traffic, University of Duisburg-Essen, 47057 Duisburg, Germany; \\ jan.eiten@uni-due.de (J.E.); ani.melkonyan@uni-due.de (A.M.) \\ * Correspondence: gruchmann@fh-westkueste.de
}

Received: 12 March 2020; Accepted: 11 April 2020; Published: 4 May 2020

check for updates

\begin{abstract}
For years, the freight forwarding industry has been facing high levels of global competition. Accelerating this development, new and digital competitors are entering the market, striving to make freight logistics even faster, cheaper, and more predictable. Digitalization processes change traditional logistics businesses, leading to more efficient, flexible, and de-centrally organized logistics services. Sea freight operations, in particular, have the potential to better fulfill customer-specific requirements in competitive and complex environments by integrating digital technologies. Therefore, it is essential to understand how automating informational processes, such as freight brokering, affect business models in the logistics service industry. The present study qualitatively analyzed the case of FreightHub, a fourth-party logistics (4PL) sea freight agency, and compared its business model with traditional third-party logistics (3PL) business models. Applying a digital business model conceptualization, the present paper presents an extended framework for digital sea freight business models. In this line, the study contributes to theory and practice by refining business model research in the maritime transportation context, and providing managerial implications about the opportunities and threats of a digital transition in this industry.
\end{abstract}

Keywords: digital business model; third-party logistics (3PL); fourth-party logistics (4PL); sea freight logistics

\section{Introduction}

Logistics provides a necessary support for much of the current economic system. In Germany, the transportation and storage of goods directly contributes about $7 \%$ of the gross domestic product (GDP), and employs about 2.5 million people. Globally, this sector has been growing faster than total GDP, as trade has expanded substantially; supply chains have become longer; and globalization has increased. Logistics activities have evolved substantially in recent decades, which has also led to a highly competitive market [1]. Accordingly, there is pressure to continuously improve the quality of logistics services and to offer them at lower prices. To relieve cost pressure, freight forwarders have attempted to break the transport process into multiple steps and to optimize each of these steps separately, which makes coordination and integrated cooperation between the parties involved more difficult. As a result, there is often no central contact with a complete overview of the entire transport chain. Such separated operations and shared responsibilities promote "silo thinking" in the logistics industry. To address such issues, new digital business models have increasingly emerged, challenging traditional, third-party logistics (3PL) business models [2]. Particularly, platform-based business models, such as Uber Freight [3], enable transparent, real-time, on-demand arrangements that cut 
into the domain of 3PL services. In this line, Hofmann and Osterwalder [2] predict that 3PL service providers focusing on standard services may lose significant market shares in the near future. Similarly, Schramm et al. [4] see a clear trend away from simply organizing transportation and logistics activities towards the providing of information technology (IT) platforms and other value-adding services, such as planning, analytics, and monitoring. Consequently, fourth-party logistics (4PL) business models are coming to the fore. These 4PL providers are seen as almost asset-free integrators between their clients and 3PLs to manage global supply chains [4,5]. While 4PL concepts and business model innovation facilitated by digital technologies have been often addressed in extant literature [6,7], special emphasis on sea freight services and maritime transportation is rather scant. Thus, the analysis of a case study, which successfully implemented a digital 4PL business model, promises further insights into the digital transformation of sea freight services. Against this background, the main objective of the present study is to assess and compare traditional 3PL business models with disruptive 4PL business models to better understand how the automation of informational processes, such as freight brokering, might affect future operations in maritime transportation. Accordingly, the following research questions (RQs) guided this study.

RQ1: What are the fundamental differences between FreightHub's business model and a traditional 3PL business model?

RQ2: What opportunities and risks does the disruptive potential of digitalization have for sea freight services and maritime transportation?

To answer these research questions, the authors applied a qualitative and conceptual approach of abductive reasoning [8], structuring the present study in the following way. Section 2.1 presents an overview on classifying services in the logistics sector, with a special emphasis on 3PL/4PL literature. Further, we analyze conceptual and empirical literature on digital business models to give an overview on the potential impact of digitalization and digital technologies on the logistics sector in general (Section 2.2), and on maritime freight transport in particular (Section 2.3). This literature review in Section 2 is followed by the case study of FreightHub in Section 3, highlighting the innovation potential of digitization within 4PL business models. Analyzing the FreightHub case, new constructs and business model elements are inductively explored, while constant comparisons with extant literature are pursued in a deductive manner. As a result, Section 4 links the existing, conceptual constructs of business model value dimensions with those empirically explored to elaborate on the effects of automating informational processes in maritime transportation, also discussing the results within a larger body of literature. Lastly, Section 5 draws conclusions from the findings, also showing the limitations of this study and potential future research avenues. This project accordingly contributes to theory, by refining business model research in the maritime transportation context, and to practice, by giving managerial implications about the opportunities and threats of a digital transition in this industry.

\section{Literature Review}

Logistics service providers constantly review their business strategies in order to provide high quality, modern services to their customers, whose requirements are becoming more demanding in the dynamic world. Thus, in this section, we firstly review and classify logistics business strategies based on attributes of their operations. Further, we carry out intensive literature analysis on digital business models in general, to apply these elements and the identified impacts of digital technologies on the maritime transportation sector with a specification on a digital FreightHub's business model.

\subsection{Classification Scheme of Business Models of Logistics Services}

In the logistics industry, business models of logistics service providers are categorized by their service range and structure. A popular classification scheme is the 1PL to 5PL scheme [9]. Single service (1PL) providers offer single logistics services, such as freight forwarding or warehousing. 
Second-party logistics (2PL) service providers carry out all classic logistics operations in transport, handling, and storage. This is a typical business model for freight forwarders, sea freight carriers, and parcel service providers. A 3PL service provider extends classic logistics to include adjacent logistics services, such as cross docking, inventory management, and packaging design [5]. In this respect, 3PL service providers are often companies that operate globally and, therefore, are able to implement advanced strategies, such as decision support systems, to optimize means of transport, routes, and capacity use. With its own assets, a 3PL service provider offers comprehensive solutions for coordinating and integrating all members of the supply chain [10]. In addition to this, 4PL service providers combine resources, capabilities, and technologies to create comprehensive supply chain solutions and provide network-integrated logistics planning and consulting [11]. Thus, 4PL service providers are often specialized consulting companies, which do not conduct any business operations of their own (so-called non-asset owning service providers). Since a 4PL provider does not have any logistics assets of its own (e.g., its own vehicle fleet or storage capacities), the services of other logistics service providers (1PL, 2PL, or 3PL) are combined for customers according to their individual requirements. As the $4 \mathrm{PL}$ provider operates exclusively in the areas of planning and coordinating using modern IT solutions, customers expect high quality service at low costs [11]. In contrast, lead logistics (5PL) service providers carry out certain operations by owning or buying physical logistics infrastructures. Since the business model of $4 \mathrm{PL} / 5 \mathrm{PL}$ providers is rather theoretical and has, so far, been limited to a niche role in practice [11], it is precisely here that digitalization offers the potential for a comprehensive digital business model to emerge. To further build on this, Tables 1 and 2 provide an overview of selected papers on 3PL and 4PL, respectively.

Summarizing the selected papers, it can be stated that the business solutions in the logistics industry have undergone a transformation, starting from the planning of locations and vehicle routing (1PL) towards advanced IT (2PL), cross-docking (3PL), and advanced pooling services (4PL to 5PL) [5]. Moreover, analyzing the literature in Tables 1 and 2, one can conclude that early research on 3PL and $4 \mathrm{PL}$ concentrated on the operational and financial performance of outsourcing logistics services. In this line, several studies explored criteria for selecting and evaluating logistics service providers. Just lately, the influence of digital technologies and a focus on specific industry sectors has been fostered. Following a similar pattern, the present study intends to contribute to a more nuanced discussion of 3PL and 4PL services by focusing on digital business models in maritime transportation beyond the still very prominent outsourcing focus.

Table 1. Selected papers on third-party logistics (3PL).

\begin{tabular}{ll}
\hline \multicolumn{1}{c}{ Study } & \multicolumn{1}{c}{ Summary } \\
\hline Gammelgaard et al. [12] & $\begin{array}{l}\text { Gammelgaard et al. [12] empirically study the role of the different parties in } \\
\text { logistics. They define three types of 3PL service providers: carriers, logistics } \\
\text { service providers, and logistics service intermediaries. The authors create a } \\
\text { collaborative logistics management model, which captures the different actors } \\
\text { and presents the information and material flows between the actors. }\end{array}$ \\
\hline Halldórsson et al. [13] & $\begin{array}{l}\text { Halldórsson et al. [13] examine whether environmental issues are a 3PL provider } \\
\text { selection criterion. Their study is based on nine cases (three 3PLs and six buyers } \\
\text { of 3PL services). The authors conclude that 3PL providers show an increased } \\
\text { interest in environmental issues on the one hand, while 3PL buyers' decisions } \\
\text { continue to strongly depend on performance targets, such as price, quality, } \\
\text { and timely delivery. }\end{array}$ \\
\hline Jayaram and Tan [14] & $\begin{array}{l}\text { Jayaram and Tan [14] have found that there are differences in the performances of } \\
\text { companies that involve logistics providers in their operations and those that do } \\
\text { not. Based on survey research, their study shows that 3PL selection criteria and } \\
\text { relationship building positively influence company performance. }\end{array}$ \\
\hline
\end{tabular}


Table 1. Cont.

\begin{tabular}{|c|c|}
\hline Study & Summary \\
\hline Lai et al. [15] & $\begin{array}{l}\text { Lai et al. [15] collect data from } 134 \text { 3PL customers to test different hypotheses. } \\
\text { After their evaluation, the authors state that relationship quality plays a critical } \\
\text { role in logistics outsourcing relationships. They show that, through } \\
\text { inter-organizational relationships and integration, customers of 3PL service } \\
\text { providers can use their dependency on those providers to effectively improve } \\
\text { their financial performance. }\end{array}$ \\
\hline Leuschner et al. [16] & $\begin{array}{l}\text { Leuschner et al. [16] carry out a meta-analytical approach and conduct a review } \\
\text { of empirical literature regarding 3PL. They find that a close and collaborative } \\
\text { relationship between the 3PL customer and the 3PL service provider can improve } \\
\text { the logistics service and overall business performance. However, they note that } \\
\text { there are no conclusive statements in the literature regarding trust and } \\
\text { commitment in 3PL-supplier-buyer relationships. Trust, therefore, should be built } \\
\text { through safeguarding mechanisms to avoid opportunistic behavior. }\end{array}$ \\
\hline Govindan and Chaudhuri [17] & $\begin{array}{l}\text { Govindan and Chaudhuri [17] analyze the risks faced by logistics service } \\
\text { providers. For this purpose, they used a multi-criteria-decision-making approach } \\
\text { called the "Decision Making Trial and Evaluation Laboratory" (DEMATEL). They } \\
\text { find that the relationship, at distance, between the logistics provider and the } \\
\text { customer is a risk, and call for more collaboration and integration. It is } \\
\text { particularly important to build up trust, which leads directly to cooperation and } \\
\text { indirectly to the development of commitment. }\end{array}$ \\
\hline Hofmann and Osterwalder [2] & $\begin{array}{l}\text { Hofmann and Osterwalder [2] particularly look at the impact of digitalization on } \\
\text { 3PL business models. By proposing a theoretical framework, they conclude that } \\
\text { logistics service providers face significant hardships from new technologies, such } \\
\text { as autonomous vehicles and 3D printing, as well as from platform-based business } \\
\text { models and the sharing economy. They further see digitalization as an } \\
\text { opportunity to enable forward or backward integration between 3PL customers } \\
\text { and their suppliers. }\end{array}$ \\
\hline Singh et al. [18] & $\begin{array}{l}\text { Singh et al. [18] state that logistics providers have an important role in making } \\
\text { cold supply chains for perishable food and pharmaceutical products more } \\
\text { efficient. The authors identify ten criteria (e.g., warehousing facilities, customer } \\
\text { service, etc.) that are suitable for the 3PL selection process. They state that 3PL } \\
\text { providers must work in cold chain under highly uncertain conditions and, } \\
\text { therefore, must develop a hybrid fuzzy approach. The results imply that a 3PL } \\
\text { provider should focus on continuous process improvement (e.g., by using } \\
\text { advanced technologies). }\end{array}$ \\
\hline
\end{tabular}

Table 2. Selected papers on fourth-party logistics (4PL).

\begin{tabular}{ll}
\hline \multicolumn{1}{c}{ Study } & \multicolumn{1}{c}{ Summary } \\
\hline Krakovics et al. [19] & $\begin{array}{l}\text { Krakovics et al. [19] create a robust performance measurement model to evaluate } \\
\text { logistics operators. They consider the case of a company, which decided to } \\
\text { terminate its direct contract with a 3PL for operating its logistics activities and, } \\
\text { instead, contracted a 4PL to handle the entire outsourcing process, and to hire } \\
\text { and monitor the necessary 3PL services needed. As a result, efficiency indicators } \\
\text { (e.g., for distribution efficiency or internal storage inventory accuracy) were } \\
\text { defined to evaluate 3PL performance and determine 4PL goals. }\end{array}$ \\
& $\begin{array}{l}\text { Hsiao et al. [20] provide a framework to analyze the effect outsourcing various } \\
\text { business activities has on logistics service performance. They show that } \\
\text { outsourcing has no direct impact on service performance (delivery reliability, } \\
\text { flexibility, and lead-time). Through network and overall supply chain } \\
\text { optimization, however, 4PL providers could step in to deal with this demand } \\
\text { complexity, as they generally have superior capabilities for combining and } \\
\text { managing different resources. }\end{array}$ \\
\hline
\end{tabular}


Table 2. Cont.

\begin{tabular}{ll}
\hline \multicolumn{1}{c}{ Study } & \multicolumn{1}{c}{ Summary } \\
\hline Hingley et al. [21] & $\begin{array}{l}\text { Hingley et al. [21] conduct an exploratory qualitative study with three } \\
\text { participating suppliers, three logistics service providers, and one grocery retailer, } \\
\text { aiming to determine the general drivers and barriers that can arise when 4PL } \\
\text { service providers are introduced to promote horizontal collaboration. The } \\
\text { authors find that large 3PL service providers can deliver 4PL services. Despite the } \\
\text { performance benefits achieved through 4PL services, 4PL providers negatively } \\
\text { impact retailer-supplier collaboration. The grocery retailer would rather keep } \\
\text { control of the supply chain than become more cost efficient with a 4PL service. }\end{array}$ \\
\hline $\begin{array}{l}\text { Saglietto [22] proposes an analysis of the 4PL community based on an empirical } \\
\text { study of all logistics service providers operating in France, using information } \\
\text { obtained from the DIANE database and selected websites. As a result, the author } \\
\text { presents a new taxonomy and definition of the 4PL, and states that 4PLs require } \\
\text { more intensive use of information technology, pooling of resources, and skilled } \\
\text { human capital than other logistics service providers. }\end{array}$ \\
$\begin{array}{l}\text { Mehmann and Teuteberg [23] examine and describe the long-term } \\
\text { implementation of 4PL in the agricultural bulk logistics sector. The authors } \\
\text { identify and validate 4PL attributes with seven case studies. The key contribution } \\
\text { of their study lies in describing the usage, benefit, and organizational structure of } \\
\text { the 4PL approach with elements of the work system theory. }\end{array}$ \\
$\begin{array}{l}\text { Schramm et al. [4] analyze the potential future of the 4PL concept based on expert } \\
\text { opinions, with a special emphasis on digitalization. Their research follows an } \\
\text { explorative mixed methods approach with semi-structured interviews and an } \\
\text { online survey questionnaire. The authors find that IT capabilities will be an } \\
\text { important differentiator for 4PL providers in the future. Further, relationships } \\
\text { between 4PL providers and their clients can become closer and more strategic, } \\
\text { which leads to a customer valuing, not only direct cost reductions, but rather } \\
\text { improvements resulting from optimized operations through superior analysis } \\
\text { and planning functions. }\end{array}$ \\
\hline Schramm et al. [4]
\end{tabular}

\subsection{Innovation Potential of Digital Business Models}

Digitalization and digital technologies have great potential for enabling business model innovation $[7,24,25]$. Several studies have analyzed how digitalization changes business models. Three changes appear prevalent: (1) Optimization of the existing business model (e.g., efficiency gains, cost optimization), (2) transformation of the existing business model (e.g., extension of the established business, extended services), and (3) development of new, disruptive business models, driven by entrepreneurial companies (e.g., new products or advanced services based on digital platforms) [7,26,27]. Digital technologies and applications that innovate business models include: The "Internet of Things" (IoT), artificial intelligence (AI), big data analytics, cloud technology, digital platforms, automation, remote monitoring, and predictive maintenance $[25,28]$. Capacities arising from these technologies in the business-to-business (B2B) context are functionality, connectivity, and analytics [25]. Digitalization can also enable a more sustainable industry $[7,28]$. Table 3 provides an overview of research and scientific papers discussing digital business models (DBMs).

Table 3. Selected papers on digital business models (DBMs).

\begin{tabular}{cl}
\hline Study & \multicolumn{1}{c}{ Summary } \\
\hline & $\begin{array}{l}\text { Porter and Heppelmann [29] examine how smart, connected products reshape competition } \\
\text { in industries and can expand industry boundaries. These products consist of three } \\
\text { elements: physical components, smart components (IT as an integral part of the product), } \\
\text { and connectivity components (additional functions in the product's cloud and its } \\
\text { interaction with other devices). Smart, connected products require companies to build and } \\
\text { support a new technology infrastructure ("technology stack"). The authors discuss ten } \\
\text { strategic choices through which companies may gain competitive advantage. These } \\
\text { include choosing between building functionalities into the product or into the cloud, } \\
\text { between internal development and outsourcing of smart capabilities and infrastructures, } \\
\text { and between the product portfolio itself and disintermediate distribution channels and } \\
\text { service networks. The authors also identify pitfalls to avoid, such as adding functionalities } \\
\text { for which customers will not pay, underestimating security and privacy risk, or failing to } \\
\text { anticipate new, competitive threats with superior technology. }\end{array}$ \\
\hline
\end{tabular}


Table 3. Cont.

\begin{tabular}{|c|c|}
\hline Study & Summary \\
\hline Porter and Heppelmann [25] & $\begin{array}{l}\text { Porter and Heppelmann [25] focus on the internal perspective and explore how smart, } \\
\text { connected products affect functions within companies. Core functions-such as product } \\
\text { development, IT, manufacturing, logistics, and marketing and sales-are affected, and new } \\
\text { functions-such as data organization or customer success management-emerge. } \\
\text { Concerning logistics, the authors state that the roots of smart, connected products are in } \\
\text { logistics, and, today, these allow for continuous tracking of products, their conditions, } \\
\text { and their surrounding environments, which bears the potential for transformation. Smart, } \\
\text { connected products allow companies to move from traditional ownership models to new } \\
\text { business models, such as the product-as-a-service model, in which customers pay for the } \\
\text { use of a product rather than buying the product itself. To support this new model, } \\
\text { companies must learn to track customer usage and satisfaction to adapt marketing and } \\
\text { service activities accordingly. }\end{array}$ \\
\hline Ehret and Wirtz [27] & $\begin{array}{l}\text { Ehret and Wirtz [27] use entrepreneurship and transaction cost theories to examine } \\
\text { conditions for designing non-ownership business models for the Industrial Internet of } \\
\text { Things (IIoT). Entrepreneurship theory, thereby, focuses on the positive form of uncertainty } \\
\text { upsides, and outlines opportunities for machine owners to offer assets and outputs as a } \\
\text { service. Transaction Cost Theory, on the other hand, stresses that IIoT opportunities enable } \\
\text { companies to better manage uncertainty downsides, and encourage users of machines to } \\
\text { give up ownership and only purchase the output. The authors identify three types of } \\
\text { IIoT-enabled business models: business models for asset-driven IIoT opportunities, } \\
\text { business models for service innovation aiding manufacturing, and service-driven business } \\
\text { models targeted at end users. Research gaps with respect to IIoT business models are seen } \\
\text { in empirical research, revealing evidence about the role of infrastructures, how best to } \\
\text { orchestrate human actors and machines, and how best to design the architecture of } \\
\text { ownership for the diverse assets needed to provide services. }\end{array}$ \\
\hline
\end{tabular}

Bressanelli et al. [28] examine the role of digital technologies (IoT, big data, analytics) as enablers of the Circular Economy (CE) in usage-focused business models. They develop a research framework to describe how eight functionalities of digital technologies affect value drivers for $\mathrm{CE}$. The eight enabling functionalities are: improving product design, attracting target customers, monitoring and tracking product activity, providing technical support, providing preventive and predictive maintenance, optimizing product usage,

Bressanelli et al. [28] upgrading the product, and enhancing renovation and end-of-life activities. The research then uses a case study to analyze how these functionalities affect the three CE value drivers: increasing resource efficiency, extending product lifespan, and closing the loop. The findings show that companies need to couple IoT with big data analytics to move to CE. Moreover, four of the functionalities increase resource efficiency and extend product lifespan in the use phase, but do not effect closing the loop. Therefore, to close the loop, companies should focus on functionalities at the start and the end of product life. Research gaps still exist with respect to product-focused and result-focused business models, as well as other digital technologies.

Rachinger et al. [26] state that a research gap exists in examining how digitalization impacts business model innovation insofar as empirical insights in this field are still limited. Therefore, they carry out a qualitative investigation, collecting data from 12 informants working in two industries: the media and the automotive industry. In their results, they outline the influences of digitalization on business model elements (value

Rachinger et al. [26] proposition, value creation, value capture) and the associations with dynamic capabilities for both industries. The findings show that digitalization is generally considered important. It is the value proposition itself, as well as the position in the value network, that determine the perceived available options for business model innovation when it comes to digitalization. The study identifies organizational capacities and employee competences as future challenges.

Annarelli et al. [30] discuss Product Service Systems (PSS) as a business model focused on providing a marketable set of sustainable products and services to fulfill customer needs. They analyze PSS using the Business Model Canvas and Business Model Innovation Process. Six key elements of a PSS business models are introduced: design of the offering,

Annarelli et al. [30]
value co-creation, functional integration with partners, degree of servitization, pre-sale and
after-sale value communication, short-term and long-term commitment, and customer
retention. Digitalization can make the transition to PSS more scalable, offering gradual

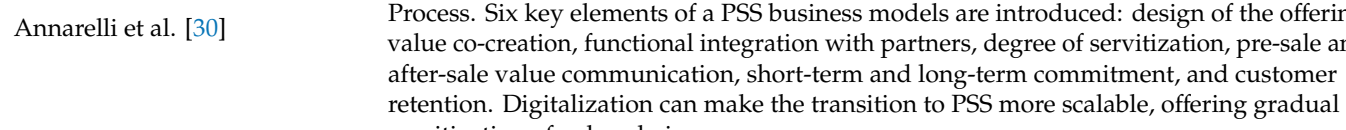

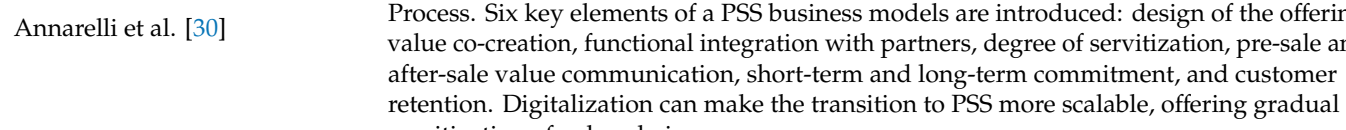
servitization of value chains.

Parida et al. [7] propose a research agenda on leveraging digitalization for business model innovation. Their literature review identifies five theoretical perspectives regarding digital business models in the B2B context: resource-based view and dynamic capabilities,

Parida et al. [7] transition theory, entrepreneurship, transaction cost theory, and platform theory. They also discuss how digitalization can enable innovation across the three business model elements of value creation, value delivery, and value capture.

Pflaum and Klötzer [31] discuss strategic approaches for transforming from product-oriented business models to data-oriented business models. They differentiate two pathways for this transition. First, companies may digitalize their own products and services, turning them into smart products and services. Second, companies may use digital solutions from third parties to make corporate processes more effective, efficient, and agile. A key consequence of transitioning toward a digital business model is that the data produced by the smart product becomes the key asset instead of the physical product itself. Furthermore pipeline-shaped supply-chains are replaced by data-driven and platform-based ecosystems with multiple corporate actors. 
Regarding the previous research, DBMs are mostly described by Business Model Canvas or business model value dimensions. The latter is used in the present study. A business model, therefore, can be described by the design of its mechanisms for (1) value creation, (2) value delivery, and (3) value capture [32]. Digitalization can drive innovation and broaden the options in all three value dimensions $[7,24,33]$. Table 4 provides an overview of these three value dimensions for DBMs and outlines the opportunities and risks for each dimension. Since the opportunities and risks arising from digitalization for the different value dimensions are manifold, key aspects were selected and grouped with a specific focus on digital B2B platform models, so they could later be applied to the FreightHub case.

Table 4. Opportunities and risks in each value dimension for digital business models.

\begin{tabular}{|c|c|c|}
\hline Value Dimensions & & Selected Opportunities and Risks for DBMs \\
\hline \multirow{2}{*}{$\begin{array}{l}\text { Value Creation: What is offered to } \\
\text { the customer? }\end{array}$} & Opportunities & $\begin{array}{l}\text { - New value drivers (instead of physical assets): Digital components, data } \\
\text { produced, data sharing, advanced services }[25,30,31] \\
\text { - Customization and tailor-made solutions [7] } \\
\text { - Changes in customer relations, e.g., continuous relationship through data } \\
\text { sharing, co-creation }[27,28]\end{array}$ \\
\hline & Risks & $\begin{array}{l}\text { - Adding unnecessary functionalities, for which customers are not willing to } \\
\text { pay }[25,29] \\
\text { - Clinging to a company-centric perspective rather than adopting an } \\
\text { ecosystem perspective }[7,33,34]\end{array}$ \\
\hline \multirow{2}{*}{$\begin{array}{l}\text { Value Delivery: How is the promised } \\
\text { value delivered to the customer? }\end{array}$} & Opportunities & $\begin{array}{l}\text { - Greater transparency and information flow through real-time data }[7,25] \\
\text { - } \\
\text { - Incmote monitoringance }[28,35] \text {. } \\
\text { - Inced sustainability [28] }\end{array}$ \\
\hline & Risks & $\begin{array}{ll}\text { - } & \text { Security and privacy risks due to shared data }[29,33] \\
\text { - } & \text { Higher interdependencies between business actors }[7] \\
\text { - } & \text { Insufficient digital capabilities and skills for delivering value }[25,26]\end{array}$ \\
\hline \multirow{2}{*}{$\begin{array}{l}\text { Value Capture: How is the value } \\
\text { delivered to the customer, } \\
\text { transformed into revenues and profits } \\
\text { for the firm? }\end{array}$} & Opportunities & $\begin{array}{l}\text { - Non-ownership business models and new pricing models } \\
\text { (e.g., subscription, pay per use) }[26,27] \\
\text { - } \quad \text { Higher or new revenue streams }[7,27] \\
\text { - Cost efficiency and more effective risk management }[7,27,31]\end{array}$ \\
\hline & Risks & $\begin{array}{l}\text { - IT infrastructure driving costs through upfront investment and continuous } \\
\text { updating }[7,29] \\
\text { Inability to capture value from digital investments by not focusing enough } \\
\text { on value capture and focusing more on other aspects, such as growing the } \\
\text { customer base }[7,33] \\
\text { Inflexible mechanisms in performance-based contracts, which do not offer } \\
\text { continuous re-negotiation of cost structures and revenue models [7] } \\
\text { - Imbalanced risk and revenue sharing in new collaborative models }[7,27]\end{array}$ \\
\hline
\end{tabular}

\subsection{Digitalization in Maritime Freight Transportation}

In maritime freight transportation, finding ideal container spaces on a vessel is a costly business for shippers/charterers. Charterers, who are unfamiliar with the shipping market, often use so-called shipping brokers, who know the market well and, therefore, can find a suitable ship with appropriate cargo space or container sites for the charterer. Accordingly, the broker mediates transport supply and demand. The services of brokers are, however, correspondingly expensive. Table 5 presents a summary of the parties involved in maritime freight transportation, their responsibilities, and the documents to be handled. Due to the large number of different actors with their various documents and contracts, managing the documents is quite a complex process. Ensuring a continuous and seamless flow of information in the transport chain is challenging. Often, documents are not immediately available, and if, for example, the customs or customs clearance documents must be presented to third parties for any reason, it can take some time for the documents to be available or to be submitted. Additionally, if customers have questions about their shipments, some of the necessary documents are often in the 
hands of an employee from another department. If this employee is also located in a different time zone, this makes coordination all the more difficult. [36]

Table 5. Actors in maritime freight transportation [36].

\begin{tabular}{|c|c|c|}
\hline Actors & Responsibilities & Documents \\
\hline Freight forwarder & Appointing the freight carrier & Forwarding contract \\
\hline Carrier & Carrying out shipment via road, rail, or inland waterway & Contract of carriage \\
\hline Terminal operator & $\begin{array}{l}\text { Handling at the port or terminal (clearance of the freight carrier, } \\
\text { temporary storage of goods) }\end{array}$ & \\
\hline Shipping broker & $\begin{array}{l}\text { Brokering charterer and shipping company (or cargo space } \\
\text { and charterer) }\end{array}$ & Charter parties (BIMCO) \\
\hline Port clearance agent & $\begin{array}{l}\text { Registering and de-registering ships with the port authorities, handling } \\
\text { customs clearance, procuring necessary equipment and provisions, etc. }\end{array}$ & $\begin{array}{l}\text { Various documents for port } \\
\text { authorities, customs, } \\
\text { and shipping company }\end{array}$ \\
\hline
\end{tabular}

\section{FreightHub's Business Model}

4PL providers operating in a maritime context generally seek to minimize costs related with sea freight brokering. FreightHub embarked on this endeavor, too, and currently partners with over 1000 carriers to quickly draw up offers for suitable shipping spaces without the high margins charged by ship brokers. FreightHub provides a central platform, called Single Source of Truth Checklists and $\mathrm{AI}$ (SCAI), which serves as an interface covering the complete process: requests for quotations, booking, document management, worldwide real-time tracking of freight, proactive problem solving, and supply chain data analysis. Thus, the entire exchange of communication and flow of information between all involved actors is available in one place. To this end, there is a joint workspace for each specific operation/order, in which the entire order process, including all the relevant documents and various reports, can be displayed with maximum transparency $[37,38]$.

With their SCAI platform, FreightHub has developed an internal system that uses new, digital technologies to meet the demand of networked operations. The basis for efficiently organizing the transport process and effectively communicating with the customer is a reliable database founded on real-time information. Customers benefit from proactive communication, particularly in situations where emerging problems can be detected and assessed in advance. This is ensured by having a single point of contact, who accompanies the customer through the entire shipping process [37,38].

Increased transparency also reduces complexity. All the data from the internal systems, the transport management system (TMS), the sales department, and business partners converge in one place and are automatically processed. This prevents data silos, which can lead to duplicate sets of data with different time stamps. It also creates very high-quality data. Every employee has real-time access, from any location, to the entire dataset of schedules, pending tasks, and previous communications. Information and documents, from the shipment booking to the delivery of the goods at the final destination, can be viewed and monitored by all employees at the same time. Instead of multiple contact persons, a central point of contact is responsible for supervising the entire transport process, from booking to delivery, and provides assistance for each step. This not only leads to higher employee satisfaction, but also to greater reliability and a better customer experience $[37,38]$.

Higher quality data aggregated in a single source also enables fast and uncomplicated data exchange and leads to agility and proactive situation analysis. FreightHub's SCAI system, using AI, makes accurate predictions at an early stage, which leads to proactive problem solving and, in turn, increasingly reliable delivery performance. Among other advantages, the customer particularly benefits from avoiding high delay charges-e.g., through warehouse overloads. Agile dispatch scheduling further enables intelligent re-routing. In sea transport, various complications can occur at loading or discharge ports, which can cost valuable time. In such events, it is difficult for customers to react in time. 
FreightHub continuously monitors the entire transport chain, and can prevent this from happening. For example, if a customer's warehouse has reached capacity, a FreightHub employee will suggest an inexpensive inland terminal for temporary storage to avoid demurrage and detention [37,38].

Digital checklists are used to process all shipments. These checklists are special because they are not only digitized, but also fully automated. Behind the checklists is an intelligent system consisting of more than 80 algorithms. The data is sorted according to urgency, and the system sends a notification if action is required. This ensures that any information requiring immediate attention appears on the screen. The automated processes again lead to data transparency, which enables all parties involved to work together smoothly and without complications. Based on the dual control principle, the system permanently checks incoming data, detects any need for action, and reports this autonomously. FreightHub states that the "most important feature, however, is [its] ability to prioritize and assign tasks to the required hierarchical level before they reach a critical stage. In the event of unscheduled developments, a previously defined responsible person at management level would be notified, whereby the warning can be linked to a defined sequence of appropriate actions" [37] (p. 12). The systematic aggregation of individual data by means of AI effectively assists risk management along the transport chain. In addition, routine, time-consuming tasks, such as filling out forms by hand, are no longer necessary. This makes "every day" work easier, and allows employees to focus on the most important tasks [37,39].

SCAI also provides the option to monitor the supply chain in real time. Through real-time updates of all shipment schedules, it is possible to track the whereabouts of each individual shipment. Shipment tracking for sea transport is carried out via Automatic Identification System (AIS) ship tracking. The AIS is a data exchange system introduced to improve shipping safety and enable the exchange of data, at national and international levels, about passengers, ships entering or leaving ports, and hazardous or environmentally harmful goods being transported by ship. The main purpose of introducing AIS is to provide a wider range of available, continuous, and reliable navigational data. It has become common practice to use data transmitted by AIS to increase shipping safety. Apart from being useful for marine traffic control, AIS data can be a very important source of information for avoiding collisions $[37,40]$.

\section{Conceptualization of a 4PL Digital Business Model in Sea Freight Logistics}

\subsection{Comparison of 3PL and 4PL Business Model Elements}

Digitalization has a major impact on maritime freight transport. However, while logistics services in sea freight are only a small part of an intermodal transport chain, there is a growing trend toward consumer-oriented, door-to-door transport being managed from a central source. When comparing the benefits of outsourcing to a 4PL service provider, such as FreightHub, with the services of a 3PL service provider, the foremost difference is that 3PL providers do not have a complete overview of the supply chain network. Since 3PL service providers rely on their own assets, it is in their interest to primarily use their own resources to capacity. In contrast, 4PL service providers, like FreightHub, operate more neutrally, and try to further reduce interfaces in the supply chain. To compare FreightHub's 4PL business model with those of 3PLs, Table 6 applies the business model dimensions of value creation, value delivery, and value capture.

Considering the opportunities digitalization provides for sea freight services and maritime transportation in a 4PL business model, the benefits go beyond purely cutting operational costs. Nonetheless, minimizing the costs of managing operational processes, such as sea freight brokering, is their main aim. Additionally, using supply-chain-wide resources through digital technologies leverages the potential of comprehensive solutions, which are not achievable when managing sole parts of the maritime transportation chain. Through advanced IT skills, 4PL business models can facilitate even closer, strategic relationships with their customers, as well as higher degrees of supply 
chain integration and coordination. This is achieved through enhanced communication, real-time data exchange and monitoring, and automated planning algorithms.

Table 6. Comparison of 3PL and 4PL business models.

\begin{tabular}{|c|c|c|c|}
\hline Value Di & ons & 3PL Business Models & 4PL Business Models \\
\hline \multirow[t]{2}{*}{ Value Creation } & Opportunities & $\begin{array}{l}\text { - Offer comprehensive solutions for } \\
\text { coordinating and integrating all } \\
\text { supply chain members [10] } \\
\text { Organize transportation and logistics } \\
\text { activities [4] }\end{array}$ & $\begin{array}{l}\text { - Combine resources, capabilities, and } \\
\text { technologies to create comprehensive } \\
\text { supply chain solutions [11] } \\
\text { Provide network-integrated logistics } \\
\text { planning and consulting [11] } \\
\text { Forge closer and more strategic } \\
\text { relationships, which lead, not only to direct } \\
\text { cost reductions, but also to improvements } \\
\text { resulting from optimized operations } \\
\text { through superior analysis and planning } \\
\text { functions [4] }\end{array}$ \\
\hline & Risks & $\begin{array}{l}\text { Depend highly on other supply chain } \\
\text { members and engage in fiercer } \\
\text { competition than } 4 \text { PL service } \\
\text { providers [41] }\end{array}$ & $\begin{array}{l}\text { Have no assets of their own, and, thus, } \\
\text { highly depend on 1PL to 3PL business } \\
\text { partners for value creation [11] } \\
\text { Require a more intensive use of IT to pool } \\
\text { resources and higher skilled human capital } \\
\text { than 3PL logistics service providers [22] }\end{array}$ \\
\hline \multirow[t]{2}{*}{ Value Delivery } & Opportunities & $\begin{array}{l}\text { - Optimize transport, routes, and } \\
\text { capacity use [10] } \\
\text { Break the transport chain into multiple } \\
\text { steps to optimize each step separately, } \\
\text { using their own assets or assets from } \\
\text { 1PL and 2PL service providers [2] }\end{array}$ & $\begin{array}{l}\text { - Use platforms as interfaces to cover the } \\
\text { complete process, particularly to foster } \\
\text { effective communication (central point of } \\
\text { contact) [37,38] } \\
\text { - Facilitate uncomplicated data exchange of } \\
\text { real-time information, in particular allowing } \\
\text { for proactive analyses (e.g., intelligent } \\
\text { re-routing) [37,38] } \\
\text { Create digital checklists (algorithms) to deal } \\
\text { with complexity [37,38] }\end{array}$ \\
\hline & Risks & $\begin{array}{l}\text { - } \quad \text { Risk data silos and silo thinking [2] } \\
\text { - Could foster opportunistic behavior } \\
\text { through missing trust [16] }\end{array}$ & $\begin{array}{l}\text { - Require achieving, developing, and } \\
\text { maintaining superior capabilities when } \\
\text { combining and managing different } \\
\text { resources [20] } \\
\text { - Places data confidentiality and security } \\
\text { at risk }\end{array}$ \\
\hline \multirow{2}{*}{ Value Capture } & Opportunities & $\begin{array}{l}\text { - Build close and collaborative } \\
\text { relationships between the 3PL } \\
\text { customer and the 3PL service provider, } \\
\text { which can improve the logistics } \\
\text { service and overall business } \\
\text { performance [16] }\end{array}$ & $\begin{array}{l}\text { - Minimize costs of sea freight brokering } \\
\text { - } \quad 37,38] \\
\text { Effectively manage risk through higher data } \\
\text { quality, increased transparency, } \\
\text { and real-time monitoring }[37,38]\end{array}$ \\
\hline & Risks & $\begin{array}{l}\text { Make 3PL buyers' decisions strongly } \\
\text { dependent on performance targets, } \\
\text { such as price, quality, and timely } \\
\text { delivery, rather than sustainability } \\
\text { performance [13] } \\
\text { Run the risk that their missing IT } \\
\text { capabilities will make one 3PL service } \\
\text { provider indistinguishable from other } \\
\text { 3PLs in the future [4] }\end{array}$ & $\begin{array}{l}\text { - Cause buyers to be highly dependent on the } \\
\text { 4PL service provider itself } \\
\text { Necessitate high degrees of trust to } \\
\text { safeguard against opportunistic behavior }\end{array}$ \\
\hline
\end{tabular}

4PL service providers offer their customers further benefits beyond maritime transportation. Non-core competencies in general logistics management can be delegated to 4PL service providers (e.g., foreign trade management, hazardous goods transportation, logistics purchasing, etc.). By leveraging legal possibilities, for example, 4PLs can reduce the tax burden on companies. They also have the necessary expertise to advise on certification processes. As different departments in large companies usually purchase logistics services independently of one another, there is no transparency regarding 
the total costs incurred. By bundling logistics management through a 4PL provider, cost transparency is regained $[4,11,36]$.

However, outsourcing sea freight logistics to a $4 \mathrm{PL}$ provider also entails certain risks, which might be higher than those related to 3PLs. Due to its complexity, a 4PL outsourcing project requires high efforts from the outsourcing company during the planning phase. The risk of becoming dependent on a 4PL service provider is accordingly high—driven even further by the longer-term contracts between the 4PL and its customer. Over time, the contracting company may lose its logistics competence. If the outsourcing company is disappointed by the 4PL service provider, whether through a lack of identification, insufficient flexibility, or diminishing performance, the decision cannot be swiftly reversed, and such changes are, at the least, less flexible than with 3PL service providers. $4 \mathrm{PL}$ outsourcing requires a high degree of trust, as the service provider has access to confidential information. If the 4PL provider works for several customers, many companies fear that sensitive data could be passed to competitors or that a competitor may be given preferential treatment. Ultimately, any failings of the $4 \mathrm{PL}$ service provider will affect the customer.

\subsection{Value Creation, Delivery, and Capture in Sea Freight Logistics}

This study informs digital business model conceptualizations by examining the empirical case of FreightHub, a 4PL service provider for maritime transportation, and applying the business model value dimensions of value creation, value delivery, and value capture. This section will elaborate on those dimensions for digital business models in sea freight and discuss the contribution of the study, while its limitations, and potential options for future research are concluded in the next section.

\subsubsection{Value Creation}

In line with Parida et al. [7], value creation refers to what is offered to the customer. Digitalization radically changes how value can be created. The physical product or service is no longer the main value driver but, rather, its digital components or even only the data produced [7,25]. Moreover, digital technologies offer to move from conventional asset-ownership to product-as-a-service models [25]. This development can already be seen in 3PL business models, in which the ownership of physical assets, such as warehouses or trucks, is less important for offering the service. Configuring advanced services based on digital platforms can provide significant opportunities for value creation $[7,34]$. Digitalization also enables customization and tailor-made solutions for customers [7]. In the FreightHub case, the integration of supply-chain-wide resources is particularly facilitated by the digital platform. DBMs also establish new customer relations. Customers' roles in the value creation process become even more important-e.g., via self-service or as a data source [7]. Customer relations is becoming more continuous and open-ended because, for example, contracts focus on the use of the product or because smart products that are purchased are still updated and keep sending data relevant for value creation long after they are bought [25]. In 4PL service providers, customer relationships can be seen as strategic, whereas, in 3PL, these relationships may be easily replaced by customers switching to another service provider. Digitalization offers possibilities to even go even further and drive collaborative value creation, where value is created beyond company boundaries and across networks into new ecosystems $[27,28,34]$. Evaluating customer needs is, therefore, crucial so that companies will not offer unwanted solutions, which are technically doable, but for which customers are not willing to pay [7,29]. In this line, using a 4PL provider enables cross-company supply chain optimization. This particularly enables small- and medium-sized companies to save great amounts on their freight costs.

\subsubsection{Value Delivery}

Value delivery describes how activities and processes are employed to deliver the value promised to the customer, including resources and capabilities [7]. Digitalization also critically changes how value is delivered to the customer $[7,24,26]$. Digital technologies improve information flow and the integration of service activities, while allowing for remote centralized process monitoring $[7,25,35]$. 
In the FreightHub case, the central platform enables uncomplicated data exchange of real-time information, creating generally higher data quality. This results in greater transparency [26,27], as well as fewer delays and more responsive customer service [7]. Bressanelli et al. [28] further outline how digitalization can contribute to more sustainability-e.g., by increasing resource efficiency or extending product lifespan. Although not directly mentioned in the FreightHub case, 4PL business models may better leverage their sustainability opportunities, as price and performance competition is less fierce.

As with value creation, digitalization drives collaboration in value delivery through storing and sharing data. On one hand, this leads to more intensified relationships and higher interdependencies [7,27]. On the other hand, data sharing increases security and privacy risks [29,33]. Another important risk can arise from insufficient organizational capacity in digital capabilities, and skills necessary to deliver the value promised $[25,26]$. Those risks must, therefore, be tackled in 4PL business models through sophisticated (digital) risk management.

\subsubsection{Value Capture}

The value capture dimension describes how a firm transforms the value delivered to customers into revenue streams and maintains financial viability [7,32]. Digitalization offers the potential for new pricing models, higher or new revenue streams, and cost reduction [7,24,26,27]. In the FreightHub case, it has lowered the costs of sea freight brokering. Digitalization can enable higher and new revenue streams via, for example, advanced services, leasing, renting, maintenance and repair, predictive modelling, process optimization, etc. [7,26]. Ehret and Wirtz [27] outline how non-ownership models can productively share uncertainties in manufacturing and service networks. In this line, outcome-based service contracts connect pricing more closely to the real value created, and allow for more flexible and customized pricing, which can be adjusted based on operational data [7]. Digital technologies can also offer cost efficiency benefits. Lower operational costs, for instance, can be achieved through process optimization and monitoring for cost-efficient resource allocation and enhanced capacities $[7,27,31]$. In addition to lower planning costs, the ability to more easily monitor delays in the schedule is one of the main benefits of FreightHub's 4PL business model.

However, developing the IT infrastructure is a substantial upfront investment, and updating it over time incurs further costs [7,29]. Despite this, many DBMs seem to put more emphasis on aspects other than value capture (e.g., growing the customer base) and seem to struggle with capturing value from their digital investments [7,33]. Data sharing and the higher level of collaboration between different business partners require thoughtful design, as well as continuous adaptation of the roles and contracts in these collaborations, to avoid imbalanced risks and revenue sharing $[7,27]$. This is especially true in performance-based contracts, which should offer flexible mechanisms allowing for continuous re-negotiation of costs structures and revenue models [7]. Nonetheless, 4PL service providers enable small- and medium-sized companies to use their own resources in a competence-oriented manner. Because 4PL service providers bundle physical, human, and technological resources, they offer smalland medium-sized companies the flexibility necessary to handle peak and highly volatile demands. Small- and medium-sized companies can also convert their fixed costs into variable costs because 4PL service providers reduce the burden their customers face to provide the resources necessary for capacity peaks.

\section{Conclusions: Contribution, Limitations, and Future Research Avenues}

The present study contributes to theory and practice by refining business model research in the maritime transportation context, and providing managerial implications about the opportunities and threats of a digital transition in this industry. However, despite its valuable insights, this study has some limitations, which may be addressed by future research. While aiming to complete the picture of how digital business models may impact maritime freight transportation, it was not possible to extensively consider all parts of the SC while analyzing FreightHub's documentation. Another limitation found in qualitative research, is the limited number of cases, which prevents the findings from being generalized. 
This limitation is explained by small and idiosyncratic samples within case studies, where data is predominantly non-numerical, thus leaving little chances to establish the probability that the data is representative of some larger population, or for the other branches [42]. This limitation implies the generalizability of the research findings being limited, which was also highlighted by Chiarini [43], who used a case study within a SME with lean production at an early stage of application. Therefore, future studies in other business models or organizational situations must test these results using survey research. Additional investigations of the links between the developed conceptualization and classical management theory will also more fully define the connections between the connections between the constructs evaluated in this paper. Future research might also tackle the link between business models and scenario analysis to further inform transformation pathways in this context [44].

Author Contributions: The authors designed the study jointly. T.G. and N.P. contributed mainly to theory building, as well as to the writing of the article. J.E. also contributed to the writing of this article. A.M. developed the initial underlying research design and contributed to the revision of the article. All authors have read and agreed to the published version of the manuscript.

Funding: This research received no external funding.

Acknowledgments: The authors like to sincerely thank Bastian Schwalenberg and Florian Funcke from Westcoast University of Applied Sciences for providing their support in conducting this study.

Conflicts of Interest: The authors declare no conflict of interest.

\section{References}

1. Gruchmann, T.; Schmidt, I.; Lubjuhn, S.; Seuring, S.; Bouman, M. Informing logistics social responsibility from a consumer-choice-centered perspective. Int. J. Logist. Manag. 2019, 30, 96-116. [CrossRef]

2. Hofmann, E.; Osterwalder, F. Third-party logistics providers in the digital age: Towards a new competitive arena? Logistics 2017, 1, 9. [CrossRef]

3. Uber Freight. Tap a Button, Book a Load. Available online: https://freight.uber.com (accessed on 1 February 2020).

4. Schramm, H.J.; Czaja, C.N.; Dittrich, M.; Mentschel, M. Current Advancements of and Future Developments for Fourth Party Logistics in a Digital Future. Logistics 2019, 3, 7. [CrossRef]

5. Gruchmann, T.; Melkonyan, A.; Krumme, K. Logistics business transformation for sustainability: Assessing the role of the lead sustainability service provider (6PL). Logistics 2018, 2, 25. [CrossRef]

6. Saglietto, L.; Cézanne, C. A bibliometric analysis of research on 4PL. Int. J. Transp. Econ. 2015, 42, 461-465.

7. Parida, V.; Sjödin, D.; Reim, W. Reviewing Literature on Digitalization, Business Model Innovation, and Sustainable Industry: Past Achievements and Future Promises. Sustainability 2019, 11, 391. [CrossRef]

8. Kovács, G.; Spens, K. Abductive reasoning in logistics research. Int. J. Phys. Distrib. Logist. Manag. 2005, 35, 132-144. [CrossRef]

9. Köylüoglu, G.; Krumme, K. Kriterienfindung für nachhaltige Geschäftsprozesse in der Logistik-Eine Aufarbeitung bestehender Probleme und möglicher Chancen. In Corporate Social Responsibility in der Logistikbranche: Anforderungen an Eine Nachhaltige Unternehmensführung; Erich Schmidt Verlag: Berlin, Germany, 2014.

10. Pflaum, A.; Gundelfinger, C.; Naumann, V.; Schwemmer, M. Transportlogistik 4.0; Fraunhofer Institut: Erlangen, Germany, 2017.

11. Becker, W.; Eierle, B.; Fliaster, A.; Ivens, B.; Leischning, A.; Pflaum, A.; Sucky, E. Geschäftsmodelle in der digitalen Welt. Strategien, Prozesse und Praxiserfahrungen; Springer Gabler: Wiesbaden, Germany, 2019.

12. Gammelgaard, B.; van Hoek, R.; Stefansson, G. Collaborative logistics management and the role of third-party service providers. Int. J. Phys. Distrib. Logist. Manag. 2006, 36, 76-92.

13. Halldórsson, Á.; Kovács, G.; Wolf, C.; Seuring, S. Environmental impacts as buying criteria for third party logistical services. Int. J. Phys. Distrib. Logist. Manag. 2010, 40, 84-102.

14. Jayaram, J.; Tan, K.C. Supply chain integration with third-party logistics providers. Int. J. Prod. Econ. 2010, 125, 262-271. [CrossRef]

15. Lai, F.; Chu, Z.; Wang, Q.; Fan, C. Managing dependence in logistics outsourcing relationships: Evidence from China. Int. J. Prod. Res. 2013, 51, 3037-3054. [CrossRef] 
16. Leuschner, R.; Carter, C.R.; Goldsby, T.J.; Rogers, Z.S. Third-party logistics: A meta-analytic review and investigation of its impact on performance. J. Supply Chain Manag. 2014, 50, 21-43. [CrossRef]

17. Govindan, K.; Chaudhuri, A. Interrelationships of risks faced by third party logistics service providers: A DEMATEL based approach. Transp. Res. Part E: Logist. Transp. Rev. 2016, 90, 177-195. [CrossRef]

18. Singh, R.K.; Gunasekaran, A.; Kumar, P. Third party logistics (3PL) selection for cold chain management: A fuzzy AHP and fuzzy TOPSIS approach. Ann. Oper. Res. 2018, 267, 531-553. [CrossRef]

19. Krakovics, F.; Leal, J.E.; Mendes Jr, P.; Santos, R.L. Defining and calibrating performance indicators of a 4PL in the chemical industry in Brazil. Int. J. Prod. Econ. 2008, 115, 502-514. [CrossRef]

20. Hsiao, H.I.; Kemp, R.G.M.; Van der Vorst, J.G.A.J.; Omta, S.O. A classification of logistic outsourcing levels and their impact on service performance: Evidence from the food processing industry. Int. J. Prod. Econ. 2010, 124, 75-86. [CrossRef]

21. Hingley, M.K.; Lindgreen, A.; Grant, D.B.; Kane, C. Using fourth-party logistics management to improve horizontal collaboration among grocery retailers. Supply Chain Manag. Int. J. 2011, 16, 316-327. [CrossRef]

22. Saglietto, L. Towards a classification of fourth party logistics (4PL). Univ. J. Ind. Bus. Manag. 2013, 1, $104-116$.

23. Mehmann, J.; Teuteberg, F. The fourth-party logistics service provider approach to support sustainable development goals in transportation-a case study of the German agricultural bulk logistics sector. J. Clean. Prod. 2016, 126, 382-393. [CrossRef]

24. Täuscher, K.; Laudien, S.M. Understanding platform business models: A mixed methods study of marketplaces. Eur. Manag. J. 2018, 36, 319-329. [CrossRef]

25. Porter, M.E.; Heppelmann, J.E. How smart, connected products are transforming companies. Harv. Bus. Rev. 2015, 93, 96-114.

26. Rachinger, M.; Rauter, R.; Müller, C.; Vorraber, W.; Schirgi, E. Digitalization and its influence on business model innovation. J. Manuf. Technol. Manag. 2019, 30, 1143-1160. [CrossRef]

27. Ehret, M.; Wirtz, J. Unlocking value from machines: Business models and the industrial internet of things. J. Mark. Manag. 2017, 33, 111-130. [CrossRef]

28. Bressanelli, G.; Adrodegari, F.; Perona, M.; Saccani, N. Exploring how usage-focused business models enable circular economy through digital technologies. Sustainability 2018, 10, 639. [CrossRef]

29. Porter, M.E.; Heppelmann, J.E. How smart, connected products are transforming competition. Harv. Bus. Rev. 2014, 92, 64-88.

30. Annarelli, A.; Battistella, C.; Nonino, F. How Product Service System Can Disrupt Companies' Business Model. In The Road to Servitization; Springer: Cham, Germany, 2019; pp. 175-205.

31. Pflaum, A.; Klötzer, C. Von der Pipeline zur Plattform-Strategische Implikationen für das Unternehmen. In Geschäftsmodelle in der Digitalen Welt; Springer Gabler: Wiesbaden, Germany, 2019; pp. 57-74.

32. Teece, D.J. Business models, business strategy and innovation. Long Range Plan. 2010, 43, 172-194. [CrossRef]

33. Teece, D.J.; Linden, G. Business models, value capture, and the digital enterprise. J. Organ. Des. 2017, 6, 8. [CrossRef]

34. Cenamor, J.; Parida, V.; Wincent, J. How entrepreneurial SMEs compete through digital platforms: The roles of digital platform capability, network capability and ambidexterity. J. Bus. Res. 2019, 100, 196-206. [CrossRef]

35. Grubic, T.; Jennions, I. Remote monitoring technology and servitised strategies-factors characterising the organisational application. Int. J. Prod. Res. 2018, 56, 2133-2149. [CrossRef]

36. Clausen, U.; Geiger, C. Verkehrs- und Transportlogistik, 2nd ed.; Springer Veiweg (VDI): Berlin, Germany, 2013.

37. FreightHub. Intelligentes Transportmanagement Dank Künstlicher Intelligenz und Algorithmen. Whitepaper. Available online: https://freighthub.com/wp-content/uploads/2020/01/FreightHub_Whitepaper_ Intelligentes_Transportmanagement-1.pdf (accessed on 1 February 2020).

38. FreightHub. E-Supply Chain: So Gelingt das Proaktive Management Ihrer Geschäftsprozesse. Available online: https://freighthub.com/de/blog/proaktives-management-der-geschaeftsprozesse/ (accessed on 1 February 2020).

39. Tüllmann, C.; Prasse, C.; Sagner, D.; Piastowski, H. Prozesse durch Digitalisierung nachhaltig optimieren. In Future Challenges in Logistics and Supply Chain Management; Fraunhofer IML: Dortmund, Germany, 2016.

40. Jaskólski, K. Availability and Integrity Model of Automatic Identification System (AIS) Information. Ph.D. Thesis, GRIN Verlag, Munich, Germany, 2014.

41. Gruchmann, T.; Seuring, S. Explaining logistics social responsibility from a dynamic capabilities perspective. Int. J. Logist. Manag. 2018, 29, 1255-1278. [CrossRef] 
42. Hodkinson, P.; Hodkinson, H. The Strengths and Limitation of Case Study Research. In Making an Impact on Policy and Practice; University of Leeds: Leeds, UK, 2001.

43. Chiarini, A. Lean production: Mistakes and limitations of accounting systems inside the SME sector. J. Manuf. Technol. Manag. 2012, 23, 681-700. [CrossRef]

44. Melkonyan, A.; Krumme, K.; Gruchmann, T.; Spinler, S.; Schumacher, T.; Bleischwitz, R. Scenario and strategy planning for transformative supply chains within a sustainable economy. J. Clean. Prod. 2019, 231, 144-160. [CrossRef]

(C) 2020 by the authors. Licensee MDPI, Basel, Switzerland. This article is an open access article distributed under the terms and conditions of the Creative Commons Attribution (CC BY) license (http://creativecommons.org/licenses/by/4.0/). 